\title{
Comparative Study of Regulatory Mechanisms for Pectinase Production by Erwinia carotovora subsp. carotovora and Erwinia chrysanthemi
}

\author{
Hiroyuki Matsumoto, ${ }^{1}$ Pongphen Jitareerat, ${ }^{1}$ Yasuhiro Baba, ${ }^{2}$ and Shinji Tsuyumu ${ }^{2}$ \\ ${ }^{1}$ United Graduate School of Agricultural Science, Gifu University (Shizuoka University), 836 Ohya, Shizuoka 422-8529, \\ Japan; ${ }^{2}$ Faculty of Agriculture, Shizuoka University, 836 Ohya, Shizuoka 422-8529, Japan
}

Submitted 3 September 2002. Accepted 4 November 2002.

The production of pectinase, the major virulence determinant of soft-rot Erwinia species, is controlled by many regulatory factors. We focused on the major regulatory proteins, KdgR, CRP, Pir, and PecS, characterized mainly in $E$. chrysanthemi, and tested for their presence and function in the control of pectate lyase (Pel) and polygalacturonase (Peh) production in $E$. carotovora subsp. carotovora. Homologues of $k d g R$ and $\operatorname{crp}$ but not of pir and pecS were detected by Southern blot analyses in $E$. carotovora subsp. carotovora. In fact, $\mathrm{KdgR}$ and $\mathrm{CRP}$ homologues of $E$. carotovora subsp. carotovora had high amino acid identities to those of $E$. chrysanthemi, including a complete match of the hypothetical helix-turn-helix DNA-binding motif. However, in Western blot analyses using anti-Pir (E. chrysanthemi) antibodies, a cross-reacting protein was present in both $\mathrm{Er}$ winia species, although Pel production in $E$. carotovora subsp. carotovora was not further stimulated by adding plant extract into the medium containing PGA (polygalacturonic acid) in which hyperinduction by Pir has been reported in $E$. chrysanthemi EC16. When plasmids that contained each of these regulatory genes from $E$. chrysanthemi were introduced into $E$. carotovora subsp. carotovora, Pel production was controlled as predicted from their roles in E. chrysanthemi, except for PecS. PecS exerted a positive control in $E$. carotovora subsp. carotovora, in contrast to a negative control in $E$. chrysanthemi. DNA-binding assays demonstrated that KdgR, CRP, Pir, and PecS of E. chrysanthemi and KdgR and CRP homologues of $E$. carotovora subsp. carotovora could bind to the promoter regions of pel1, pel-3, and peh of E. carotovora subsp. carotovora. Taken together, KdgR and CRP homologues of $E$. carotovora subsp. carotovora may regulate Pel and Peh production as in E. chrysanthemi. However, the presence of Pir and PecS homologues in $E$. carotovora subsp. carotovora was not identified in this study, though these proteins of $E$. chrysanthemi were functional on the promoter regions of the pectinase genes of $E$. carotovora subsp. carotovora.

Erwinia carotovora subsp. carotovora, E. carotovora subsp. atroseptica, and E. chrysanthemi are widely distributed in the world and cause serious damage on a wide variety of plants (Perombelon and Kelman 1980). Cell wall-degrading enzymes (Barras et al. 1994; Kotoujansky 1987), such as pectate lyase (Pel), polygalacturonase $(\mathrm{Peh})$, cellulase $(\mathrm{Cel})$, and protease

Corresponding author: S. Tsuyumu; Telephone and Fax: +81-54-2384823; E-mail: tsuyumu@agr.shizuoka.ac.jp.
(Prt), are considered to be the main factors responsible for pathogenicity. These enzymes are produced and secreted into the external milieu in large quantities. Of these enzymes, Collmer and Keen (1986) noted that Pel and Peh play a crucial role in pathogenicity.

The production of these extracellular enzymes is affected by various environmental factors such as the presence of pectin and plant extracts, cell density, temperature, nitrogen starvation, oxygen or iron concentration, and osmolarity (HugouvieuxCotte-Pattat et al. 1992, 1996; Robert-Baudouy et al. 2001). Previous studies identified a number of regulatory genes involved in the production of these enzymes in E. chrysanthemi and E. carotovora subsp. carotovora, such as pir (E. chrysanthemi), pecS-pecM (E. chrysanthemi), fur (E. chrysanthemi), hns (E. chrysanthemi), crp (E. chrysanthemi), aepA (E. carotovora subsp. carotovora), rexZ (E. carotovora subsp. carotovora), hor (E. carotovora subsp. carotovora), pehR-pehS (E. carotovora subsp. carotovora), expA-expS (E. carotovora subsp. carotovora), expM (E. carotovora subsp. carotovora), rpoS (E. carotovora subsp. carotovora), rsmA-rsmB-rsmC (E. carotovora subsp. carotovora), pecT (E. chrysanthemi)/hexA (E. carotovora subsp. carotovora), $k d g R$ (E. chrysanthemi and E. carotovora subsp. carotovora), and expI-expR (E. chrysanthemi and E. carotovora subsp. carotovora) (Andersson et al. 1999a, 1999b, 2000; Cui et al. 1995, 1999; Eriksson et al. 1998; Flego et al. 2000; Franza et al. 1999; Harris et al. 1998; Liu et al. 1999; Murata et al. 1991, 1994; Nasser et al. 1998, 2001; Nomura et al. 1998; Pirhonen et al. 1993; Reverchon et al. 1991, 1994, 1997; Surgey et al. 1996; Thomson et al. 1997, 1999).

In E. chrysanthemi, $\mathrm{KdgR}$ is the major negative regulatory protein responsible for the control of the expression of genes involved in the degradation and catabolism of pectic compounds (Nasser et al. 1994; Reverchon et al. 1991). In vitro experiments showed that specific binding of the KdgR repressor to the operators of these genes is inhibited by a pectic catabolic product, 2-keto-3-deoxygluconate (KDG) (Nasser et al. 1991). Pel production of E. chrysanthemi is further stimulated by the presence of one or more additional plant factors only in synergy with pectic compounds (Hugouvieux-Cotte-Pattat et al. 1992). Such hyperinduction of Pel is controlled by Pir activator in E. chrysanthemi EC16 (Nomura et al. 1998), although the chemical nature of the additional inducing factors in plant extracts is not yet known. From preliminary characterization of one inducing factor from carrot root, the factor could be an oligosaccharide (Bourson et al. 1993).

Besides these plant-responsive regulatory proteins in the bacteria, several global regulators have been reported. CRP 
(cyclic AMP receptor protein) is required for the full expression of pectinolysis genes (Reverchon et al. 1997) mediated by the cAMP-CRP complex (Kolb et al. 1993). Other global regulators are PecS and PecT, which negatively regulate the expression of pel genes (Castillo and Reverchon 1997; Praillet et al. 1996; Reverchon et al. 1994; Surgey et al. 1996), although the signal or signals for those regulators are unknown.

Most of these factors are involved in other aspects of virulence, such as protein secretion, motility, EPS synthesis, iron capture, and the production of pigment, cellulase, and protease (Robert-Baudouy et al. 2001). In addition, recent results indicate several interactions between these regulatory systems (Andersson et al. 1999b; Cui et al. 1995, 1999, 2001; Hyytiainen et al. 2001; Liu et al. 1999; Mukherjee et al. 1998, 2000; Reverchon et al. 1998). Robert-Baudouy and associates (2001) have indicated that regulation of pectinase synthesis in soft-rot Erwinia species seems to be a complex network involving multiple regulatory systems. However, only a few regulators have been found in both E. chrysanthemi and E. carotovora subsp. carotovora to date; most others have been described in only one or the other. Even when common regulators have been reported, such as HexA (E. carotovora subsp. carotovora) or PecT (E. chrysanthemi) and ExpR (E. carotovora subsp. carotovora and $E$. chrysanthemi), their regulatory effects have been distinguishable in both species (Andersson et al. 2000; Harris et al. 1998). Thus, in this study, we tested for the presence of homologues of the representative regulatory genes $k d g R, c r p$, pir, and pecS found in E. chrysanthemi and for their activities in the control of $\mathrm{Pel}$ and Peh production in E. carotovora subsp. carotovora.

\section{RESULTS}

Pel production of $E$. carotovora subsp. carotovora and $E$. chrysanthemi strains in various media.

Pel production by E. carotovora subsp. carotovora and E. chrysanthemi strains was confirmed to be induced in yeast extract-peptone (YP) medium containing polygalacturonic acid (PGA) but was repressed in YP medium containing glucose (Table 1). These results suggest that KdgR and CRP homologues of E. carotovora subsp. carotovora may function in a similar manner to E. chrysanthemi. The addition of potato extract or Chinese cabbage extract (data not shown) with PGA into YP or M63-glycerol minimal medium, however, did not hyperinduce Pel production in either E. carotovora subsp. carotovora strain or in E. chrysanthemi 3937, while E. chrysanthemi EC16 exhibited a typical hyperinduction in minimal medium. In previous work, E. chrysanthemi 3937 was shown to hyperinduce Pel production in minimal medium containing PGA and plant extract, although the production was significantly affected by various environmental parameters, such as carbon source, temperature, and nitrogen or oxygen availability (Hugouvieux-Cotte-Pattat et al. 1992). Accordingly, minor differences in the incubation of bacterial cells, such as temperature, shaking speed, and the plant extracts used, might have concealed the hyperinduction of Pel in E. chrysanthemi 3937 in this study.

\section{E. chrysanthemi $k d g R$ and $\operatorname{crp}$ homologues in E. carotovora subsp. carotovora.}

Southern blot analyses for EcoRI digests (Fig. 1) and for $B a m H I$ digests (data not shown) of the total DNAs from $E$. carotovora subsp. carotovora EC1, E. chrysanthemi 3937, and $E$. chrysanthemi EC16 strains were performed using polymerase chain reaction (PCR) products of $k d g R$, $c r p$, and pecS of E. chrysanthemi 3937 and pir of E. chrysanthemi EC16 as probes. Signal bands for $k d g R$ and $c r p$ homologues were detected not only in E. chrysanthemi strains but also in E. carotovora subsp. carotovora EC1. Thus, $k d g R$ and crp seem to be present both in E. chrysanthemi and in E. carotovora subsp. carotovora. In fact, $k d g R$ has already been isolated and reported in other strains of E. carotovora subsp. carotovora (Liu et al. 1999; Thomson et al. 1999). However, no signal was detected for pir and pecS in E. carotovora subsp. carotovora EC1, even under the low-stringency hybridizing conditions of Southern blot analyses.

From a genomic library of E. carotovora subsp. carotovora $\mathrm{EC} 1$, clones from the regions homologous to $k d g R$ and $c r p$ of E. chrysanthemi 3937 were obtained. Open reading frames (ORF) encoding 263 and 210 amino acid residues were found within the subclones of $\mathrm{pKdgR}(2.5 \mathrm{E})$ and $\mathrm{pCRP}(3.5 \mathrm{~B})$, respectively. The $\mathrm{KdgR}$ homologue of E. carotovora subsp. carotovora $\mathrm{EC} 1$ had more than $98.1 \%$ and $92.8 \%$ amino acid identities to those of other strains of E. carotovora subsp. carotovora and E. chrysanthemi 3937, respectively. The CRP homologue of $E$. carotovora subsp. carotovora $\mathrm{EC} 1$ had $97.6 \%$ amino acid identity to that of E. chrysanthemi 3937 . In either case, amino acid sequences corresponding to a potential helix-turn-helix (HTH) DNA-binding motif (based on the data in SWISSPROT) completely matched those of E. chrysanthemi 3937 (Fig. 2).

\section{Immunologically related Pir}

in E. carotovora subsp. carotovora strains.

In Western blot analyses of total cell lysates of E. carotovora subsp. carotovora and E. chrysanthemi strains using

Table 1. Pel activity ${ }^{\mathrm{a}}$ of Ecc and $\mathrm{Ech}^{\mathrm{b}}$ strains in various media

\begin{tabular}{|c|c|c|c|c|c|c|c|c|}
\hline \multirow[b]{3}{*}{ Medium } & \multicolumn{8}{|c|}{ Strain } \\
\hline & \multicolumn{2}{|c|}{ Ecc EC1 } & \multicolumn{2}{|c|}{ Ecc 71} & \multicolumn{2}{|c|}{ Ech EC16 } & \multicolumn{2}{|c|}{ Ech 3937} \\
\hline & Sup. & Total & Sup. & Total & Sup. & Total & Sup. & Total \\
\hline YP & $8.0 \pm 1.4$ & $11.1 \pm 1.2$ & $37.6 \pm 1.6$ & $39.3 \pm 1.5$ & $2.9 \pm 1.2$ & $7.6 \pm 2.7$ & $14.7 \pm 7$ & $23.3 \pm 5.9$ \\
\hline YP+Glucose & $0.6 \pm 0.1$ & $1.3 \pm 0.1$ & $1.9 \pm 0.1$ & $3.0 \pm 0.4$ & $3.2 \pm 0.8$ & $4.5 \pm 1.6$ & $5.8 \pm 2.6$ & $8.2 \pm 2.7$ \\
\hline $\mathrm{YP}+\mathrm{PGA}$ & $86.6 \pm 6.8$ & $93.6 \pm 6.9$ & $97.0 \pm 4.1$ & $102.7 \pm 2.0$ & $31.2 \pm 2.6$ & $36.3 \pm 3.9$ & $66.1 \pm 10.2$ & $80.7 \pm 11.0$ \\
\hline $\mathrm{YP}+\mathrm{PGA}+\mathrm{Po}^{\mathrm{c}}$ & $92.3 \pm 7.4$ & $97.0 \pm 13.0$ & $126.7 \pm 20.1$ & $136.3 \pm 18.1$ & $35.5 \pm 14.0$ & $45.7 \pm 12.6$ & $67.2 \pm 11.9$ & $76.0 \pm 13.2$ \\
\hline M63 ${ }^{\mathrm{d}}$ & $1.2 \pm 0.8$ & $2.6 \pm<0.1$ & $2.1 \pm 0.2$ & $14.9 \pm 2.9$ & $4.5 \pm 0.5$ & $\mathrm{NT}^{\mathrm{e}}$ & $15.9 \pm 4.4$ & NT \\
\hline M63+PGA & $124.1 \pm 32.7$ & $138.5 \pm 39.2$ & $82.7 \pm 5.3$ & $93.4 \pm 3.0$ & $58.3 \pm 44.7$ & NT & $377.8 \pm 64.5$ & NT \\
\hline M63+PGA+Po & $102.4 \pm 4.4$ & $106.7 \pm 3.8$ & $63.2 \pm 7.7$ & $75.6 \pm 11.8$ & $528.1 \pm 196.5$ & NT & $379.4 \pm 79.0$ & NT \\
\hline
\end{tabular}

${ }^{\mathrm{a}} \mathrm{Pel}$ activity was expressed as the $\mathrm{U} / \mathrm{OD}_{660}$ of the bacterial culture. Bacterial strains were grown in indicated medium at $27^{\circ} \mathrm{C}$ until early stationary phase and then fractionated. The data was expressed as the mean of at least three independent experiments.

${ }^{\mathrm{b}}$ Ecc $=$ Erwinia carotovora subsp. carotovora $;$ Ech $=$ E. chrysanthemi .

${ }^{\mathrm{c}}$ Potato extract.

${ }^{d}$ M63-glycerol minimal medium.

${ }^{\mathrm{e}}$ Not tested. 
monoclonal antibodies raised against Pir of E. chrysanthemi EC16, a signal similar in molecular mass (about $30 \mathrm{kDa}$ ) to that estimated $(30.1 \mathrm{kDa})$ for EC16 Pir (Nomura et al. 1998) was detected in all strains tested, although the signals were weaker than those of E. chrysanthemi EC16 (Fig. 3). Thus, Pir may be present not only in E. chrysanthemi strains but also in E. carotovora subsp. carotovora strains. Furthermore, proteins immunologically related to Pir were found in other Erwinia spp., including E. carotovora subsp. atroseptica, E. herbicola pv. milletiae, and E. rhapontici, but not in other bacteria, such as Pseudomonas syringae and Agrobacterium tumefaciens (data not shown). Though Pir has been shown to bind specifically to the promoter regions of pel genes (pelA$E)$ and pectin-catabolizing genes $(o g l, k d g K)$ in E. chrysanthemi EC16 (Nomura et al. 1998), the protein may be required for a function other than that of a regulator, leading to the hyperinduction of Pel.

\section{Dosage effects of $E$. chrysanthemi regulatory genes on Pel production in E. carotovora subsp. carotovora.}

Introduction of the plasmid carrying a regulatory gene such as $k d g R, \operatorname{crp}, \operatorname{pec} T$, hexA, аepA, gacA, gacS, expR, rsmA, aepH $(r s m B)$, or $r s m C$ into soft-rot Erwinia species was shown to affect Pel production (Andersson et al. 2000; Castillo and Reverchon 1997; Cui et al. 1999, 2001; Harris et al. 1998; Liu et al. 1993; Ma et al. 2001; Mukherjee et al. 2000; Murata et al. 1994; Reverchon et al. 1997; Thomson et al. 1999), although the degree of effect to Pel production is somewhat dependent on the copy number of vector used. Thus, we tested such gene dosage effects in E. carotovora subsp. carotovora EC1-N (Table 2) after introduction of the plasmids carrying the individual gene $k d g R$, crp, or pecS of E. chrysanthemi 3937 or pir of E. chrysanthemi EC16. In YP medium, the additional $k d g R$ copies decreased Pel production, while the presence of $c r p$ or pir increased Pel production, compared with that of the vector control (Fig. 4). Accordingly, Pel production in E. carotovora subsp. carotovora may be regulated by the homologues of these molecules in a manner similar to that in E. chrysanthemi (Nomura et al. 1998; Reverchon et al. 1991, 1997). Unexpectedly, pecS increased Pel production in E. carotovora subsp. carotovora EC1-N, although it has been reported as a negative regulator in E. chrysanthemi 3937 (Reverchon et al. 1994). When bacteria were grown in the medium containing PGA, no clear positive effects on Pel production by CRP, Pir, or PecS were observed. Surprisingly, the presence of $k d g R$ increased Pel production in E. carotovora subsp. carotovora EC1-N compared with that in the vector control. High production of
$\mathrm{KdgR}$ might contribute to the activation of Pel production in the medium containing PGA by an unknown mechanism.

\section{Binding of $E$. chrysanthemi KdgR, CRP, Pir, and PecS to the promoter regions \\ of $E$. carotovora subsp. carotovora pel-1, pel-3, and peh.}

Using purified $\mathrm{KdgR}, \mathrm{CRP}$, and $\mathrm{PecS}$ of E. chrysanthemi 3937 and Pir of E. chrysanthemi EC16, gel-mobility shift assays were conducted to test the abilities of the proteins to bind to the promoter regions of pel-1, pel-3, and peh of E. carotovora subsp. carotovora. The promoter region of $E$. chrysanthemi pelE, which has been reported to bind to all of these proteins, was used as the positive control (Nomura et al. 1998; Rouanet et al. 1999). Bands of all the promoter fragments tested were shifted by these E. chrysanthemi regulatory proteins (Fig. 5), indicating that the promoters of $E$. carotovora subsp. carotovora have recognition sites for these E. chrysanthemi regulatory proteins. The binding efficiencies of $\mathrm{KdgR}, \mathrm{CRP}$, and Pir of E. chrysanthemi to the promoter regions of E. carotovora subsp. carotovora seemed to be lower than those to E. chrysanthemi pelE, except in the case of PecS. In binding assays using purified KdgR and CRP of E. carotovora subsp. carotovora EC1, however, the binding efficiency did not significantly differ compared with those of E. chrysanthemi (data not shown). Thus, the low binding efficiencies of $\mathrm{KdgR}$ and $\mathrm{CRP}$ (E. chrysanthemi and E. carotovora subsp. carotovora equally) to the promoter regions of $E$. carotovora subsp. carotovora seem to result from a difference in the promoter sequences in which these regulatory molecules bind. In the case of Pir, the binding efficiencies to the promoter regions of E. carotovora subsp. carotovora were indistinguishable from that of E. chrysanthemi pelE in binding assays under low-ionic strength conditions (Fig. 5). However, no band of the E. chrysanthemi-Pir complex with the E. carotovora subsp. carotovora promoter regions was observed at high-ionic strengths, while the band with $E$. chrysanthemi pelE was clearly observed under similar conditions (data not shown). Thus, the binding efficiencies of $E$. chrysanthemi Pir to the E. carotovora subsp. carotovora promoter regions seemed to be lower than that to E. chrysanthemi pelE. On the other hand, PecS formed an intense band with both the E. carotovora subsp. carotovora and E. chrysanthemi promoter regions, even in high-ionic strength conditions, and a broad region was protected in DNaseI footprinting assays, depending on the concentration of protein (data not shown). These results may be due to the fact that $\mathrm{PecS}$ has been reported to bind preferably at the AT-rich region in E. chrysanthemi 3937 (Praillet et al. 1996).

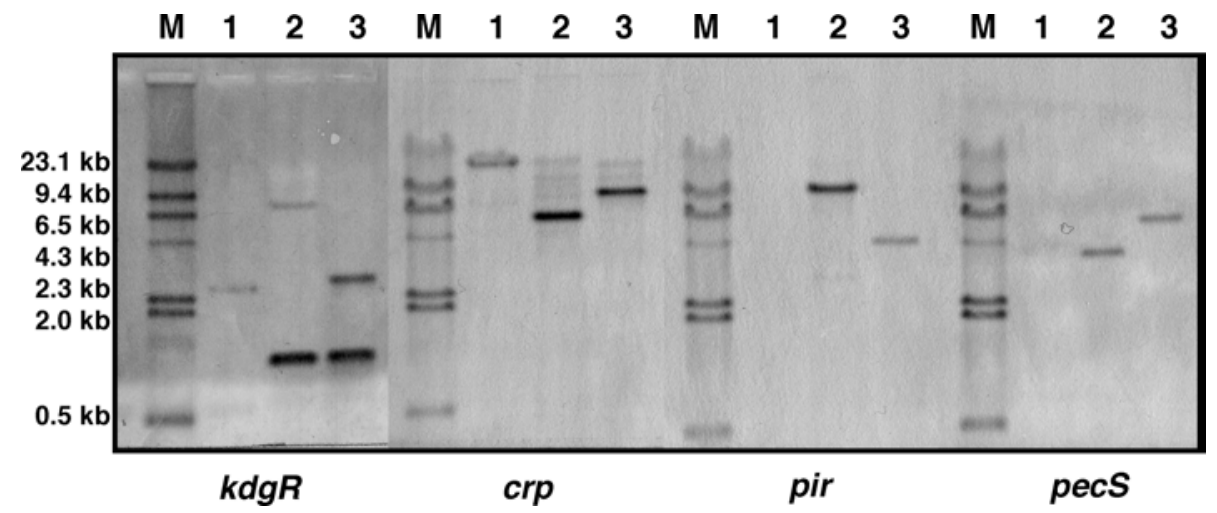

Fig. 1. Southern blot analyses of EcoRI-digested DNAs from Erwinia carotovora subsp. carotovora EC1, E. chrysanthemi EC16, and E. chrysanthemi 3937 using E. chrysanthemi regulatory genes as the probes. The hybridization was done at $60^{\circ} \mathrm{C}$. Lane M, DIG-labeled $\lambda$-HindIII marker; lanes 1 to 3 , total EcoRI-digested DNAs of E. carotovora subsp. carotovora EC1, E. chrysanthemi EC16, and E. chrysanthemi 3937. 
Induction of $E$. carotovora subsp. carotovora pel-1, pel-3, and peh and E. chrysanthemi pelE

in $E$. carotovora subsp. carotovora and in $E$. chrysanthemi.

$\mathrm{Tn} 7$ integrants that have a single insertion of each of the promoter-lux fusions into their chromosomes (Shen et al. 1992) were constructed for the expression studies of E. carotovora subsp. $c a$ rotovora pel-1, pel-3, and peh and E. chrysanthemi pelE, both in E. carotovora subsp. carotovora EC1-N and in E. chrysanthemi EC16. In YP medium containing PGA, expression of each of these genes was induced in both species (Fig. 6). These data suggest that KdgR of both species may be functional on the promoter regions of these genes of both species. It is noteworthy that, in both species, E. chrysanthemi pelE expression seemed to be tightly repressed in YP medium and highly induced in the medium containing PGA compared with expression of E. carotovora subsp. carotovora pel-1, pel-3, and peh. On the other hand, E. carotovora subsp. carotovora peh expression was highly inducible in E. carotovora subsp. carotovora EC1-N grown in YP medium containing PGA but not in E. chrysanthemi EC16. Therefore, some other positive factor or factors for the full induction of $E$. carotovora subsp. carotovora peh expression may be present in $E$. carotovora subsp. carotovora but not in E. chrysanthemi.

Expression of E. carotovora subsp. carotovora pel-1, pel-3, and peh in a pir-deficient mutant of $E$. chrysanthemi EC16.

The expression of E. carotovora subsp. carotovora pel-1 and peh in a pir-deficient mutant (K2367) of E. chrysanthemi
EC16 was lower than in the wild-type strain grown in M63glycerol minimal medium containing PGA and potato extract in which Pel activity is hyperinduced (Fig. 7). Thus, Pir of $E$. chrysanthemi EC16 may act as the positive factor for the expression of E. carotovora subsp. carotovora pel-1 and peh under these conditions. The expression level of $E$. carotovora subsp. carotovora pel-3 in E. chrysanthemi EC16 was not high, even under the hyperinductive conditions relative to the other cases. We can not conclude, then, that Pir of E. chrysanthemi EC16 is functional on the promoter region of E. carotovora subsp. carotovora pel-3 in this experiment.

\section{DISCUSSION}

$\mathrm{KdgR}$ and CRP homologues of E. carotovora subsp. carotovora $\mathrm{EC} 1$ had high amino acid identities to those of $E$. chrysanthemi 3937 (92.8 and 97.6\%, respectively), including a complete match of the hypothetical HTH motif. As expected from this information, KdgR and CRP homologues of E. carotovora subsp. carotovora $\mathrm{EC} 1$ were indistinguishable from those of E. chrysanthemi 3937 in DNA-binding assays (data not shown). Therefore, the lower binding efficiencies of KdgR and CRP (E. chrysanthemi and E. carotovora subsp. carotovora equally) to the promoter regions of E. carotovora subsp. carotovora pel genes and peh, compared with those of E. chrysanthemi pelE, seemed to result from the differences in their binding regions on these genes. Among the pel genes in E.

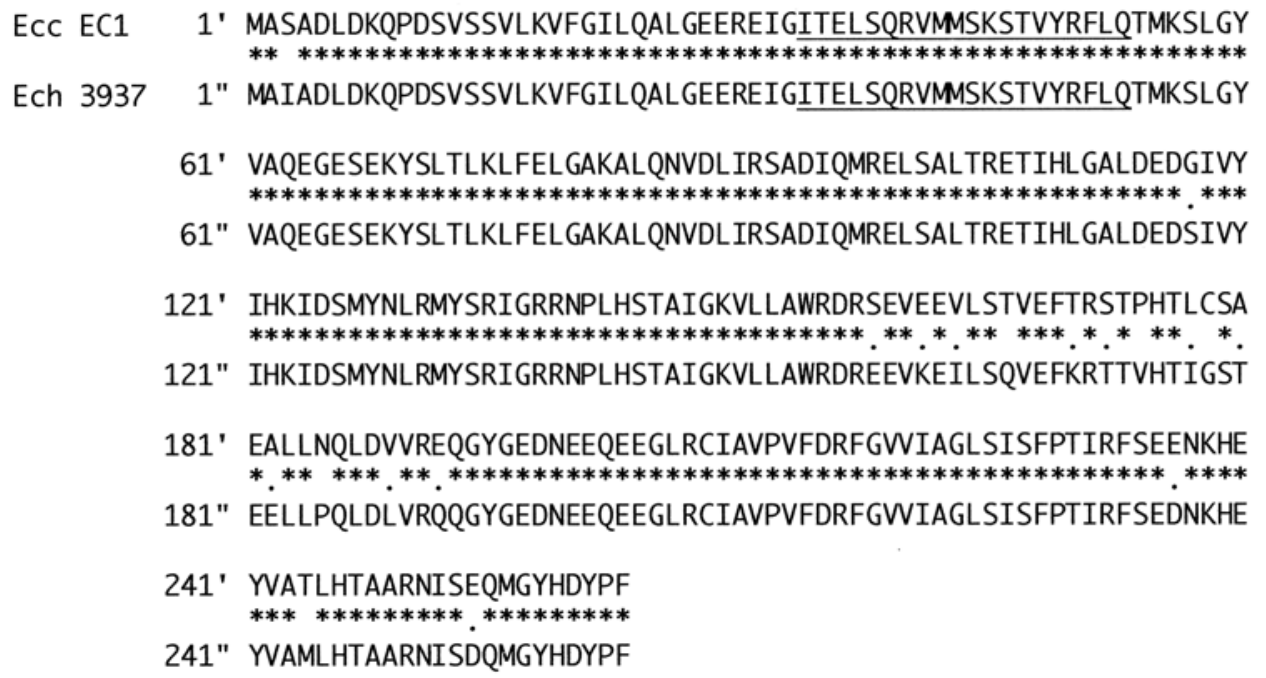

ECC EC1

Ech 3937
1' MVLGKPQTDPTLEWFLSHCHIHKYPSKSTLIHQGEKAETLYYIVKGSVAVLIKDEEGKEM $* * * * * * * * * * * * * * * * * * * * * * * * * * * * * * * * * * * * * * * * * * * * * * * * * * * * * * * * * * * * *$ 1" MVLGKPQTDPTLEWFLSHCHIHKYPSKSTLIHQGEKAETLYYIVKGSVAVLIKDEEGKEM

61' ILSYLNQGDFIGELGLFEEGQERSAWVRAKTACEVAEISYKKFRQLIQVNPDILMRLSAQ $* * * * * * * * * * * * * * * * * * . * * * * * * * * * * * * * * * * * * * * * * * * * * * * * * * * * * * * * * * . *$ 61" ILSYLNQGDFIGELGLFEDGQERSAWVRAKTACEVAEISYKKFRQLIQVNPDILMRLSSQ

121' MASRLQVTSEKVGNLAFLDVTGRIAQTLLNLAKQPDAMTHPDGMQIKITRQEIGQIVGCS **.******.*****.******************************************** 121" MARRLQVTSQKVGNLGFLDVTGRIAQTLLNLAKQPDAMTHPDGMQIKITRQEIGQIVGCS

181' RETVGRILKMLEDQNLISAHGKTIVVYGTR $* * * * * * * * * * * * * * * * * * * * * * * * * * * * * *$ 181" RETVGRILKMLEDQNLISAHGKTIVVYGTR

\section{KdgR}

\section{CRP}

Fig. 2. Alignments of deduced amino acid sequences of KdgR and CRP homologues of Erwinia carotovora subsp. carotovora EC1 with those of E. chrysanthemi 3937. Potential helix-turn-helix motifs are underlined. Identical amino acids and similar amino acids are shown as asterisks and dots, respectively. 
chrysanthemi 3937, expression of pelD, a homologue of pelE in E. chrysanthemi EC16, is most severely affected by changes in culture conditions, including induction by pectic compounds (Hugouvieux-Cotte-Pattat et al. 1992). In this study, the expression of E. chrysanthemi pelE (EC16) was also highly induced relative to that of E. carotovora subsp. carotovora pel genes and peh, both in E. chrysanthemi and in E. carotovora subsp. carotovora. Although the binding studies were carried out in vitro while the expression studies were done in vivo, the different binding efficiencies of KdgR and CRP (and Pir) to the promoter regions of E. carotovora subsp. carotovora (pel-1, pel-3, and peh) and E. chrysanthemi (pelE) may reflect different controls for the level of expression of each gene, such as the induction efficiency by pectic compounds, rather than a difference in the regulatory mechanisms of pectinase genes in both species.

Surprisingly, in the medium containing PGA, the increase in the dosage of gene $k d g R$ of E. chrysanthemi 3937 elevated Pel production in E. carotovora subsp. carotovora EC1-N compared with that in the vector control (Fig. 4). Because KdgR of E. chrysanthemi 3937 was shown to be released from the operator by the interaction with KDG in vitro (Nasser et al. 1991), the activation effect by its gene dosage may result from one or more indirect mechanisms, such as the interaction of released $\mathrm{KdgR}$ with one or more other negative regulatory molecules.

On the other hand, the gene dosage effect of crp was not clearly observed in the medium containing PGA (Fig. 4). From the analyses of simultaneous binding of KdgR and CRP to the promoter regions of several pectinolysis genes in E. chrysanthemi, Nasser and associates (1997) showed that binding of both proteins could be either competitive or independent. Even in the case of competition, however, $\mathrm{KdgR}$ is preponderant because the preferential and exclusive binding of $\mathrm{KdgR}$ leads to the prevention of RNA polymerase binding. Thus, release of KdgR repressors from the operators may be critical for the activation of Pel production. In a noninducing medium, the increase in the dosage of gene $c r p$ seems to alleviate the prevention of RNA polymerase binding mediated by KdgR (Fig. 4). Peh production in E. carotovora subsp. carotovora strains seemed not to be subjected to catabolite repression in YP or M63-glycerol minimal medium containing glucose, although it was induced in medium containing PGA (data not shown). The weak binding in vitro of CRP to the promoter region of E. carotovora subsp. carotovora peh may not reflect the situation in vivo.

Although a protein immunologically related to Pir in the genus Erwinia was detected by Western blot analyses using monoclonal antibodies raised against Pir of E. chrysanthemi EC16, amino acid identity of Pir between E. chrysanthemi EC16 and E. chrysanthemi 3937 is $91.5 \%$ (85.5\% at DNA level), even in same species. In the case of PecS, its homologue in Erwinia carotovora species was not detected even by Western blot analysis using antibodies raised against PecS of E. chrysanthemi 3937 (Praillet et al. 1996). Accordingly, overall structures of the Pir and PecS homologues in E. carotovora subsp. carotovora may not be similar to those of E. chrysanthemi, even if the homologues exist between the species. However, both proteins of E. chrysanthemi, in fact, elevated Pel production in E. carotovora subsp. carotovora and bound to the promoter regions of E. carotovora subsp. carotovora pel genes and peh. Thus, the binding sites for these regulators should be present.

In E. carotovora subsp. carotovora strains, the use of plant extracts did not hyperinduce Pel activity in YP or M63-glycerol minimal medium containing PGA in this study. In addition, extra copies of pir from E. chrysanthemi EC16 could not clearly elevate Pel production in E. carotovora subsp. carotovora $\mathrm{EC} 1-\mathrm{N}$ in the presence of PGA relative to that of the vector control, nor was induction seen after the addition of plant extract to the medium (data not shown). For some reason, the use of plant extract in the presence of PGA seemed to be ineffective for hyperinducing Pel in E. carotovora subsp. carotovora. One or more plant extract molecules might be unable to enter E. carotovora subsp. carotovora cells in view of the fact that the expression of E. carotovora subsp. carotovora pel-1 and peh in E. chrysanthemi EC16 was under the control of pir and was hyperinduced by the addition of plant extract into the medium containing PGA. As to Pir function, Pir was reported to bind to a DNA sequence that overlaps the KdgR-binding site, competing with KdgR in E. chrysanthemi EC16 (Nomura et al. 1998). Accordingly, Pir may behave as an antirepressor against KdgR to control pelE transcription in E. chrysanthemi EC16. Also, PecS, which was initially isolated as a repressor from $E$. chrysanthemi 3937 , has recently been shown to act as an activator of the transcription of polygalacturonase genes pehV, pehW, and pehX (Nasser et al. 1999). In a review by Robert-Baudouy and associates (2001), the mechanism of antirepression exerted by Pir or PecS was suggested as an efficient way to increase the transcription of a limited set of genes controlled by the main repressor KdgR. These observations are correlated with the finding that gene dosage effects of pir or pecS of E. chrysanthemi were not clearly observed in E. carotovora subsp. carotovora in the medium containing PGA, as they were for crp (Fig. 4). Thus, E. chrysanthemi Pir and PecS

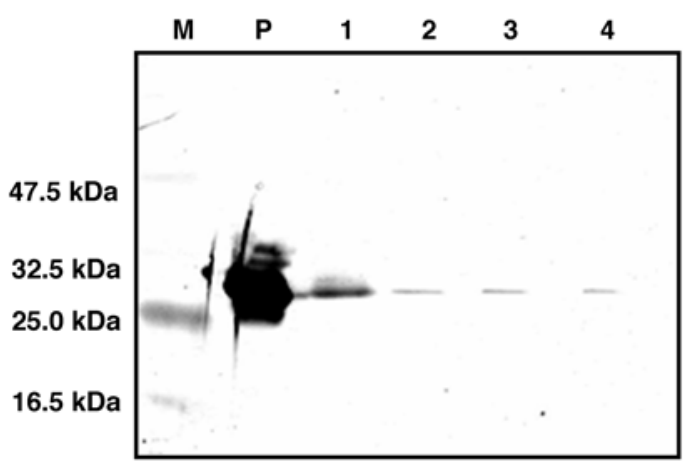

Ech

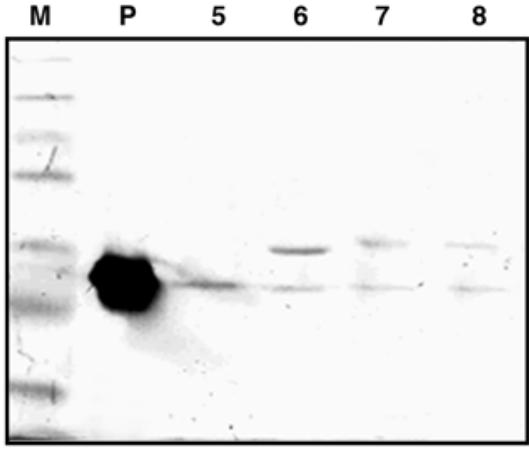

Ecc

Fig. 3. Western blot analyses of total cell lysates from Erwinia chrysanthemi and from E. carotovora subsp. carotovora strains using monoclonal antibodies raised against Pir of E. chrysanthemi EC16. Bacterial cells were grown in M63-glycerol minimal medium containing $0.2 \%$ polygalacturonic acid and $1 \%$ potato extract at $27^{\circ} \mathrm{C}$ until early stationary phase. Lane M, prestained molecular weight marker; lane P, purified Pir of E. chrysanthemi EC16; lanes 1 to 4, total cell lysates of E. chrysanthemi strains of EC16, 3937, EC183, and D7; lanes 5 to 8, total cell lysates of E. carotovora subsp. carotovora strains of $\mathrm{EC} 1,71, \mathrm{~T} 29$, and DB15. 
homologues in E. carotovora subsp. carotovora seem to function merely as antirepressors against $\mathrm{KdgR}$ for the control of Pel and, possibly, of Peh production.

In this study, we found that KdgR and CRP homologues of E. carotovora subsp. carotovora may regulate Pel and Peh pro- duction as they do in E. chrysanthemi. However, the presence of Pir and PecS homologues in E. carotovora subsp. carotovora was not concluded here, although these proteins of $E$. chrysanthemi were functional on the promoter regions of pectinase genes of E. carotovora subsp. carotovora.

Table 2. Bacterial strains and plasmids

\begin{tabular}{|c|c|c|}
\hline Strain or plasmid & Relevant characteristics & Source or reference \\
\hline \multicolumn{3}{|c|}{ Erwinia carotovora subsp. carotovora } \\
\hline EC1 & Wild type & Laboratory collection \\
\hline EC1-N & Spontaneous $\mathrm{Nal}^{\mathrm{r}}$ mutant of $\mathrm{EC} 1, \mathrm{Nal}^{\mathrm{r}}$ & This study \\
\hline 71 & Wild type & $\begin{array}{l}\text { A. K. Chatterjee, University of } \\
\text { Missouri }\end{array}$ \\
\hline $\mathrm{T} 29$ & Wild type & A. K. Chatterjee \\
\hline DB15 & Wild type & A. K. Chatterjee \\
\hline \multicolumn{3}{|l|}{ Erwinia chrysanthemi } \\
\hline EC16 & Wild type & A. K. Chatterjee \\
\hline K2367 & pir $^{-}$derivative of EC16, $\mathrm{Km}^{\mathrm{r}}$ & Nomura et al. 1998 \\
\hline 3937 & Wild type & Kotoujansky et al. 1982 \\
\hline EC183 & Wild type & A. K. Chatterjee \\
\hline D7 & Wild type & A. K. Chatterjee \\
\hline \multicolumn{3}{|l|}{ Esherichia coli } \\
\hline DH10B & $\begin{array}{l}\mathrm{F}^{-} \text {mcrA } \Delta(\text { mrr-hsdRMS-mcrBC }) \phi 80 \mathrm{~d} l a c Z \Delta \mathrm{M} 15 \Delta \text { acX } 74 \text { deoR recA1 endA1 araD139 } \\
\Delta(\text { ara, leu }) 7697 \text { galU galK } \lambda^{-} \text {rpsL nupG }\end{array}$ & Invitrogen, Carlsbad, CA, U.S.A. \\
\hline HB101 & $\mathrm{F}^{-} h s d S\left(\mathrm{r}_{\mathrm{B}}^{-} \mathrm{m}_{\mathrm{B}}^{-}\right)$thi pro leu lacY ara xyl supE recAl3 & Sambrook et al. 1989 \\
\hline BL21(DE3) & $\mathrm{F}^{-} d c m$ ompT hsdS gal $\lambda(\mathrm{DE} 3)$ & Novagen, Madison, WI, U.S.A. \\
\hline \multicolumn{3}{|l|}{ Plasmid } \\
\hline pLAFR3 & Broad host range vector, Tet ${ }^{\mathrm{r}}$ & Staskawicz et al. 1987 \\
\hline pUC118 & Cloning vector, $\mathrm{Amp}^{\mathrm{r}}$ & Takara, Tokyo, Japan \\
\hline pHSG298 & Cloning vector, $\mathrm{Km}^{\mathrm{r}}$ & Takara \\
\hline pCR-Script SK(+) & Cloning vector, $\mathrm{Amp}^{\mathrm{r}}$ & Stratagene, La Jolla, CA, U.S.A. \\
\hline pBluescript SK(-) & Cloning vector, $\mathrm{Amp}^{\mathrm{r}}$ & Stratagene \\
\hline pET-21a(+) & $\mathrm{T} 7$ overexpression vector, $\mathrm{Amp}^{\mathrm{r}}$ & Novagen \\
\hline pHSK728 & Tn7-lux transcriptional fusion vector, $\mathrm{Amp}^{\mathrm{r}}, \mathrm{Sp}^{\mathrm{r}} / \mathrm{Stm}^{\mathrm{r}}$ & Shen et al. 1992 \\
\hline pMON7181 & Helper plasmid carrying genes for $\mathrm{Tn} 7$ transposition, $\mathrm{Gm}^{\mathrm{r}}$ & Barry 1988 \\
\hline pMON7184 & Helper plasmid carrying genes for Tn7 transposition, Tet $^{r}$ & Barry 1988 \\
\hline pRK2013 & Helper plasmid carrying genes for conjugation, $\mathrm{Km}^{\mathrm{r}}$ & Figurski and Helinski 1979 \\
\hline $\mathrm{pKdgR}(2.5 \mathrm{E})$ & 2.5-kb EcoRI fragment containing $k d g R$ of EClcloned into the same site of pUC118 & This study \\
\hline pCRP(3.5B) & 3.5-kb Bam HI fragment containing $\operatorname{crp}$ of EC1cloned into the same site of pUC118 & This study \\
\hline pKdgR-3937 & $\begin{array}{l}\text { 1.3-kb PCR product containing } k d g R \text { of } 3937 \text {, processed with BamHI and HindIII, cloned } \\
\text { into the same sites of pLAFR } 3\end{array}$ & This study \\
\hline pCRP-3937 & $\begin{array}{l}\text { 1.2-kb PCR product containing } c r p \text { of } 3937 \text {, processed with EcoRI and HindIII, cloned into } \\
\text { the same sites of pLAFR3 }\end{array}$ & This study \\
\hline pPir-EC16 & $\begin{array}{l}\text { 1.2-kb PCR product containing pir of EC16, processed with EcoRI and HindIII, cloned into } \\
\text { the same sites of pLAFR3 }\end{array}$ & This study \\
\hline pPecS-3937 & $\begin{array}{l}\text { 0.8-kb PCR product containing pecS of 3937, processed with EcoRI and HindIII, cloned into } \\
\text { the same sites of pLAFR } 3\end{array}$ & This study \\
\hline pET-K3 & $\begin{array}{l}\text { 801-bp PCR product containing } k d g R \text { ORF of } 3937 \text {, processed with } N d e \mathrm{I} \text { and } B a m \mathrm{HI} \text {, cloned } \\
\text { into the same sites of pET21-a(+) }\end{array}$ & This study \\
\hline pET-C3 & $\begin{array}{l}\text { 655-bp PCR product containing } \text { crp ORF of 3937, processed with NdeI and BamHI, cloned } \\
\text { into the same sites of pET21-a (+) }\end{array}$ & This study \\
\hline pET-PIR & pET21-a(+) derivative containing pir ORF of EC16 under the T7 promoter & Nomura et al. 1999 \\
\hline pTP1 & $\begin{array}{l}\text { pT7-5 (T7 overexpression vector) derivative containing pecS ORF of } 3937 \text { under the T7 } \\
\text { promoter, Amp }\end{array}$ & Praillet et al. 1996 \\
\hline pET-KE & $\begin{array}{l}\text { 801-bp PCR product containing } k d g R \text { ORF of EC1, processed with } N d e \text { I and BamHI, cloned } \\
\text { into the same sites of pET21-a(+) }\end{array}$ & This study \\
\hline pET-CE & $\begin{array}{l}\text { 655-bp PCR product containing } \operatorname{crp} \text { ORF of EC1, processed with NdeI and BamHI, cloned } \\
\text { into the same sites of pET21-a(+) }\end{array}$ & This study \\
\hline pPEL1-R & $\begin{array}{l}\text { 323-bp PCR product containing pel-1 promoter region }(-174 \text { to }+131) \text { of } 71 \text {, processed with } \\
\text { XmaI and } P \text { st I, cloned into the same sites of pCR-Script SK }(+)\end{array}$ & This study \\
\hline pPEL3-R & $\begin{array}{l}\text { 298-bp PCR product containing pel-3 promoter region }(-199 \text { to }+77) \text { of } 71 \text {, processed with } \\
X m a \mathrm{I} \text { and } P \text { stI } \text {, cloned into the same sites of pCR-Script SK }(+)\end{array}$ & This study \\
\hline pPEH-R & $\begin{array}{l}\text { 286-bp PCR product containing peh promoter region }(-68 \text { to }+218) \text { of EC1, treated with } \\
\text { Klenow fragment, cloned into the HincII site of pHSG } 298\end{array}$ & This study \\
\hline pPEH-RL & $\begin{array}{l}\text { Bam HI-PstI fragment containing peh promoter region from pPEH-R cloned into the same } \\
\text { sites of pBluescript SK(-) }\end{array}$ & This study \\
\hline pHS001 & 2.3-kb HindIII-SmaI fragment containing pelE of EC16 cloned into the same sites of pUC118 & K. Nomura, lab collection \\
\hline pPEL1-LUX & $\begin{array}{l}\text { XmaI-EcoRI fragment containing pel-1 promoter region from pPEL-1R cloned into the same } \\
\text { sites of pHSK728 }\end{array}$ & This study \\
\hline pPEL3-LUX & $\begin{array}{l}\text { XmaI-EcoRI fragment containing pel-3 promoter region from pPEL-3R cloned into the same } \\
\text { sites of pHSK } 728\end{array}$ & This study \\
\hline pPEH-LUX & $\begin{array}{l}\text { BamHI-EcoRI fragment containing peh promoter region from pPEH-RL cloned into the same } \\
\text { sites of pHSK } 728\end{array}$ & This study \\
\hline pPELE-LUX & $\begin{array}{l}\text { NdeI-MluI fragment }(-150 \text { to }+110) \text { containing pelE promoter region from pHS001, blunted } \\
\text { with Klenow fragment, cloned into SmaI site of pHSK728 }\end{array}$ & Nomura et al. 1998 \\
\hline
\end{tabular}




\section{MATERIALS AND METHODS}

Bacterial strains, plasmids, and growth media.

Bacterial strains and plasmids used in this study are described in Table 2. The strains of E. carotovora subsp. carotovora and $E$. chrysanthemi were grown in YP medium (1\% peptone, $0.5 \%$ yeast extract, $\mathrm{pH} 6.8$ ) at $27^{\circ} \mathrm{C}$. Escherichia coli strains were grown in LB (Luria-Bertani) medium $(1 \%$ tryptone, $0.5 \%$ yeast extract, $0.5 \% \mathrm{NaCl}, \mathrm{pH} 7.0$ ) at $37^{\circ} \mathrm{C}$. M63 medium (Miller 1972) containing 0.2\% glycerol was used as minimal medium. When required, carbon sources and antibiotics were added as follows: PGA (0.2\%), glucose $(0.2 \%)$, nalidixic acid (Nal, $30 \mu \mathrm{g}$ per $\mathrm{ml})$, ampicillin $(50 \mu \mathrm{g}$ per ml), kanamycin $(50 \mu \mathrm{g}$ per $\mathrm{ml})$, streptomycin (Stm, $25 \mu \mathrm{g}$ per $\mathrm{ml})$, spectinomycin $(\mathrm{Sp}, 100 \mu \mathrm{g}$ per $\mathrm{ml})$, and tetracycline (Tet, $12.5 \mu \mathrm{g}$ per ml). Plate media were solidified by the addition of $1.5 \%$ agar. Plant extracts were prepared by autoclaving vegetables $(100 \mathrm{~g} / \mathrm{l})$ that had been cut into small pieces. Resultant supernatant $(1 / 10 \mathrm{vol})$ was added to the medium.

\section{Pel activity assay.}

Bacterial cells were grown at $27^{\circ} \mathrm{C}$ until early stationary phase by measuring optical cell density at $660 \mathrm{~nm}\left(\mathrm{OD}_{660}\right)$ (BACTOMONITOR BACT-500, Intertech Inc., Tokyo). The culture supernatant was prepared by centrifuging $1 \mathrm{ml}$ of the culture at 15,000 rpm for $2 \mathrm{~min}$. To determine total activity, the supernatant of the sonicated bacterial culture was used after sedimenting the cell debris. One $\mathrm{ml}$ of the cell suspension was sonicated two times for $20 \mathrm{~s}$ (Ultrasonic Disrupter UD-200, Tomy, Tokyo) on ice. Pel activity was assayed, essentially as described by Zink and associates (1985). Sample solution (10 $\mu \mathrm{l})$ was added to $990 \mu \mathrm{l}$ of the reaction buffer $(0.05 \%$ PGA, 0.1 M Tris- $\mathrm{HCl}, \mathrm{pH} 8.5,0.1 \mathrm{mM} \mathrm{CaCl}{ }_{2}$ ), prewarmed at $30^{\circ} \mathrm{C}$. Following a thorough mixing, the increase in the $\mathrm{OD}_{230}$ was measured every minute (Ultrospec 3000, Pharmacia Biotech, Cambridge, U.K.). One unit of Pel activity was defined as the enzyme that produced a change in absorbance of 0.001 at 230 $\mathrm{nm}$ in one minute.

\section{Recombinant DNA techniques.}

Preparation of total and plasmid DNA, PCR, restriction digestion, ligation, DNA electrophoresis, electroporation, and sodium dodecyl sulfate-polyacrylamide gel electrophoresis (SDS-PAGE) were done essentially as described by Ausubel and associates (1987) or Sambrook and associates (1989). EMBL3 BamHI Arms Cloning System (Promega, Madison, WI, U.S.A.) was used for the construction of genomic library of E. carotovora subsp. carotovora $\mathrm{EC} 1$ according to instructions. Nucleotide sequence analysis was performed with a DNA-Autosequencer (Li-cor, Lincoln, NE, U.S.A.). Restriction and modifying enzymes were purchased from Nippon Gene (Toyama, Japan) and New England Biolabs (Beverly, MA, U.S.A.). Primer sequences used in this study are available upon request.

\section{Southern blot hybridization.}

Southern blot hybridization was performed essentially as described by Sambrook and associates (1989). For preparation and detection of the probe, PCR DIG Labeling Mix (Roche, Mannheim, Germany) and DIG Chem-Link Labeling and Detection Set (Roche) were used, respectively. Procedures were done according to the manufacturer's instructions.

\section{Preparation of monoclonal antibodies.}

Monoclonal antibodies were generated essentially as described by Ausubel and associates (1987). Mouse (BALB/c line, 7 weeks old) was immunized using $100 \mu \mathrm{l}$ of $500 \mu \mathrm{g}$ of $E$. chrysanthemi EC16 per ml purified Pir after mixing with an equal volume of complete (first time) or incomplete Bacto Freund's adjuvant ( 2 weeks after the first injection, at intervals of 1 week, three times) (Difco, Detroit, MI, U.S.A.). One week after the last booster injection, spleen cells were isolated and fused with mouse myeloma NS-1 cells. Of 233 hybridoma cell lines, a single clone that produced useful antibodies was selected by repeated cloning and screening of the single hybridoma cells. The culture supernatant resulting from sedimentation of the cells by centrifugation at $2,500 \mathrm{rpm}$ for $10 \mathrm{~min}$ was used as the monoclonal antibody.

\section{In YP}

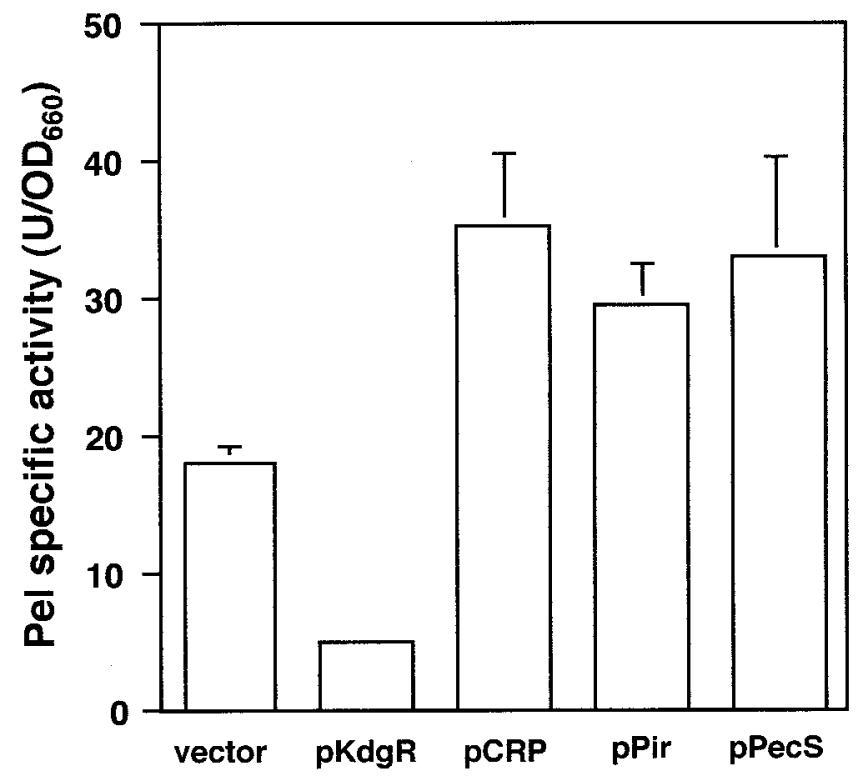

In YP+PGA

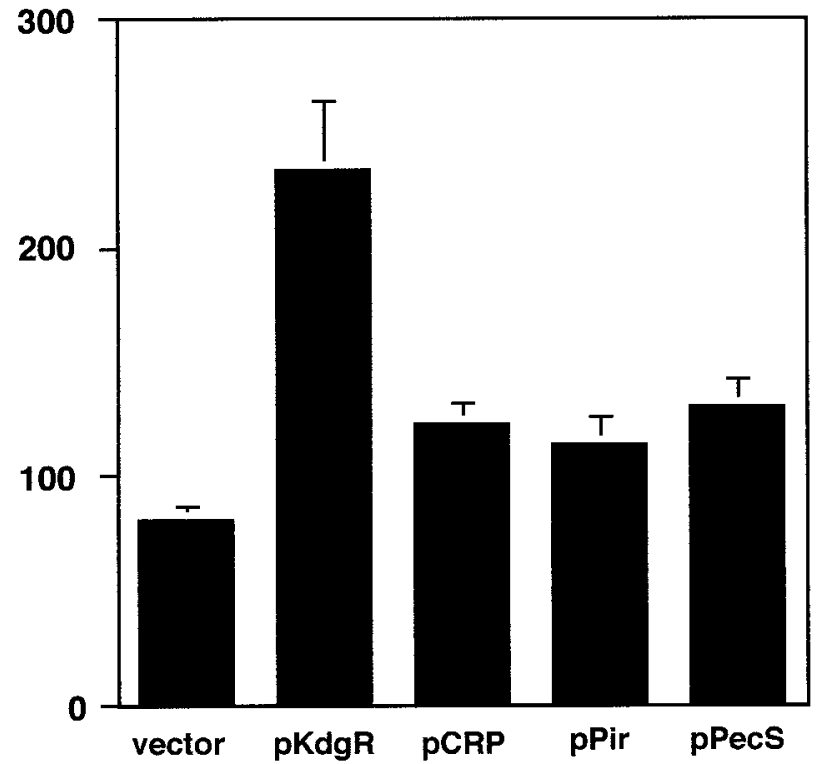

Fig. 4. Pel activity of Erwinia carotovora subsp. carotovora EC1 containing clone plasmids for E. chrysanthemi regulatory molecules. Plasmid DNA was introduced into E. carotovora subsp. carotovora EC1-N by triparental mating using HB101 harboring pRK2013 as the helper strain. The bacterial cells were grown at $27^{\circ} \mathrm{C}$ until early stationary growth phase in indicated medium. Data are expressed as the mean of Pel-specific activity (U/OD 660 ) of sonicated bacterial cultures from at least three independent experiments. 


\section{Western blot hybridization.}

After proteins were separated on a $10 \%$ SDS-PAGE gel, the gel was washed in transfer buffer C $(25 \mathrm{mM}$ Tris-base, $40 \mathrm{mM}$ boric acid, 15\% methanol, 0.04\% SDS) for $20 \mathrm{~min}$. Using a PolyBlot Transfer System (American Bionetics, Hayward, CA, U.S.A.), proteins in the gel were blotted onto a Hybond-P PVDF membrane (Amersham Pharmacia Biotech, Buckinghamshire, U.K.). Assembly was as follows: the anode to the cathode, two No. 1 filter papers (Whatman, Maidstone, U.K.) presoaked in transfer buffer A ( $0.3 \mathrm{M}$ Tris-base, $15 \%$ methanol, $0.04 \%$ SDS), two filter papers presoaked in transfer buffer B (25 mM Tris-base, 15\% methanol, 0.04\% SDS), a PVDF membrane pretreated with $100 \%$ methanol for $5 \mathrm{~s}$ and then soaked in transfer buffer $\mathrm{C}$, a gel presoaked in transfer buffer $\mathrm{C}$, and two filter papers presoaked in transfer buffer C. Proteins were electrotransferred at $0.8 \mathrm{~mA} / \mathrm{cm}^{3}$ for $1 \mathrm{~h}$, followed by electro-

A

$\begin{array}{lllllllllllllllllllll}0 & 1 & 2 & 3 & 4 & 0 & 1 & 2 & 3 & 4 & 0 & 1 & 2 & 3 & 4 & 5 & 0 & 1 & 2 & 3 & 4\end{array}$

KdgR

B

$\begin{array}{lllllllllllllllllllllll}0 & 1 & 2 & 3 & 4 & 5 & 0 & 1 & 2 & 3 & 4 & 5 & 0 & 1 & 2 & 3 & 4 & 5 & 0 & 1 & 2 & 3 & 4\end{array}$

CRP

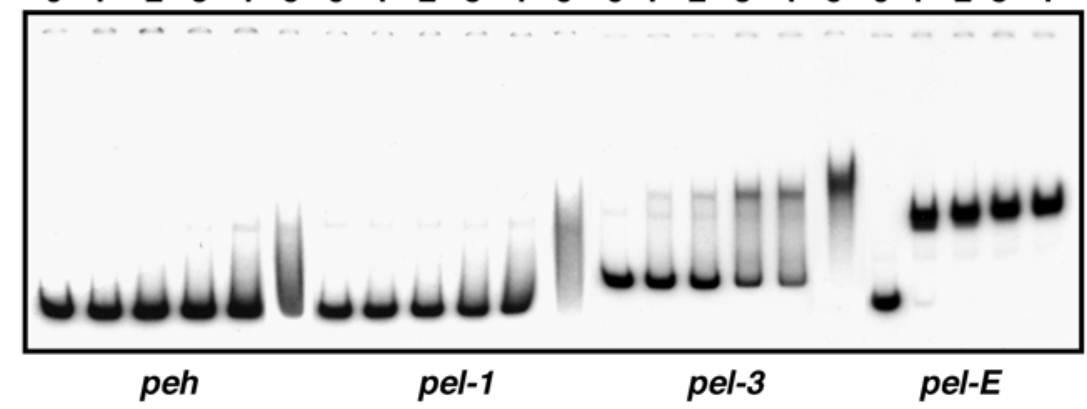

C

$\begin{array}{llllllllllllllllllll}0 & 1 & 2 & 3 & 4 & 0 & 1 & 2 & 3 & 4 & 0 & 1 & 2 & 3 & 4 & 0 & 1 & 2 & 3 & 4\end{array}$

Pir

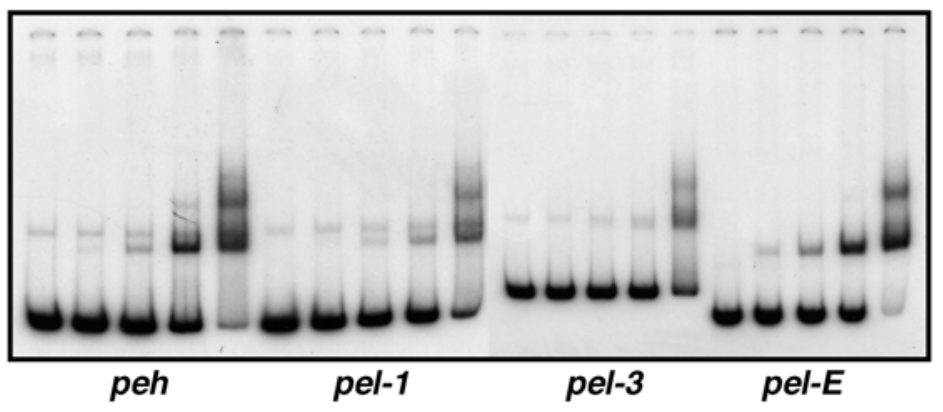

D

$\begin{array}{llllllllllllllllllll}0 & 1 & 2 & 3 & 4 & 0 & 1 & 2 & 3 & 4 & 0 & 1 & 2 & 3 & 4 & 0 & 1 & 2 & 3 & 4\end{array}$

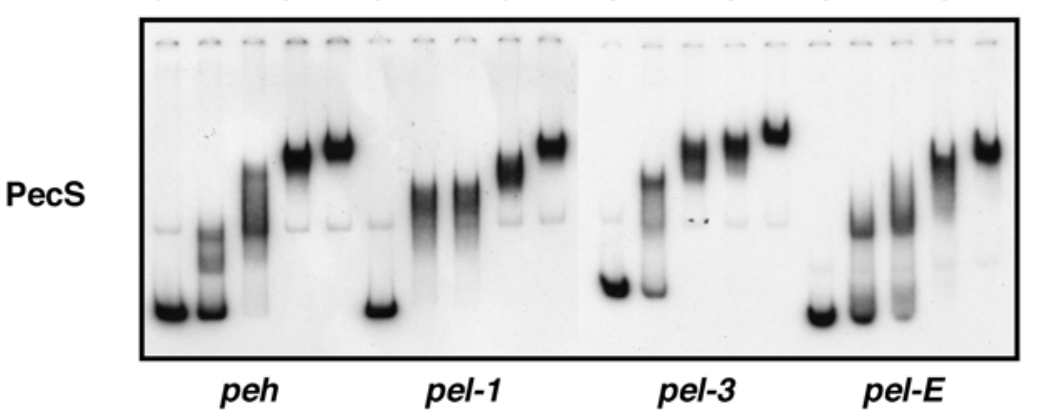

Fig. 5. Gel-mobility shift assays of the promoter regions of Erwinia carotovora subsp. carotovora peh, pel-1, and pel-3 and E. chrysanthemi pelE using purified E. chrysanthemi KdgR, CRP, Pir, and PecS under low-ionic strength conditions. A, Lanes 0 to 5 correspond to incubation with 0, 10, 25, 40, 55, and $110 \mathrm{nM}$ purified $\mathrm{KdgR}$, respectively. B, Lanes 0 to 5 correspond to incubation with 0, 20, 40, 80, 160, and 320 nM purified CRP (cyclic AMP receptor protein), respectively. C, Lanes 0 to 4 correspond to incubation with $0,1.5,6,25$, and $100 \mathrm{nM}$ purified Pir, respectively. D, Lanes 0 to 4 correspond to incubation with $0,20,40,80$, and $160 \mathrm{nM}$ purified $\mathrm{PecS}$, respectively. 
transfer at $2.5 \mathrm{~mA} / \mathrm{cm}^{3}$ for $30 \mathrm{~min}$. After the transfer, the membrane was rinsed in PBS buffer $(137 \mathrm{mM} \mathrm{NaCl}, 2.5 \mathrm{mM} \mathrm{KCl}$, $\left.8 \mathrm{mM} \mathrm{Na} 2 \mathrm{HPO}_{4} \cdot 12 \mathrm{H}_{2} \mathrm{O}, 1.5 \mathrm{mM} \mathrm{KH} \mathrm{PO}_{4}\right)$ and then blocked in the same buffer containing $5 \%$ skim milk and $0.3 \%$ TritonX100 for $2 \mathrm{~h}$ at room temperature. Then, the membrane was washed three times in PBS buffer containing $0.3 \%$ TritonX100 (washing buffer) for $15 \mathrm{~min}$. After sedimenting anti-Pir monoclonal-antibody-producing cells by centrifugation at 2,500 rpm for $10 \mathrm{~min}$, one-third volume of the culture supernatant in washing buffer was used as the primary antibody. The membrane was incubated for $2 \mathrm{~h}$ at room temperature. After three 15-min buffer washes, the membrane was incubated with a 1/1000 volume of a secondary antibody (AP conjugated antimouse antibody, Biolabs, Beverly, MA, U.S.A.) in washing buffer for $2 \mathrm{~h}$ at room temperature. Following three 15-min buffer washes, the membrane was developed in AP luminescent buffer (100 mM Tris- $\mathrm{HCl} \mathrm{pH} 9.5,100 \mathrm{mM} \mathrm{NaCl}, 50 \mathrm{mM}$ $\mathrm{MgCl}_{2} \cdot 6 \mathrm{H}_{2} \mathrm{O}$ ) containing $0.1 \%$ 4-nitro blue tetrazolium (NBT) and $0.1 \% \mathrm{X}$-phosphate (BCIP).

\section{Preparation of operator fragments for binding study.}

DNA fragments cut from the plasmids, pPEL-1R (XmaIPst I), pPEL-3R (XmaI-PstI), pPEH-R (XmaI-Pst I), and pHS001 (NdeI-MluI) (Table 2) cut with restriction enzymes were end-labeled with $100 \mu \mathrm{Ci}$ of $\left[\alpha-{ }^{32} \mathrm{P}\right] \mathrm{dCTP}(3,000 \mathrm{Ci} / \mathrm{mmol}$; $1 \mathrm{Ci}=37 \mathrm{GBq}$ ) and the Klenow fragment of DNA polymerase I. These labeled fragments were electrophoresed, excised, and extracted using QIAEX II Gel Extraction Kit (Qiagen, Hilden, Germany).
Overexpression and purification of regulatory proteins.

$\mathrm{T} 7$ overexpression vector constructs containing $k d g R$, crp, pir, or pecS were introduced into Escherichia coli BL21(DE3) by electroporation using Cell-Porator (set at $18.4 \mathrm{kV} / \mathrm{cm}, 300$ $\mu \mathrm{F}$, and 4 ohms; Gibco BRL Life Technologies, Gaithersburg, MD). Among the transformants, single cells that were sufficiently overexpressing the protein were selected by incubation in $3 \mathrm{ml}$ of LB medium, as described later. Then, the cells were streaked onto plates of LB agar and were incubated at $37^{\circ} \mathrm{C}$ overnight. The freshly prepared cells were collected and grown in $400 \mathrm{ml}$ of $\mathrm{LB}$ liquid medium at $37^{\circ} \mathrm{C}$ until cell density reached an $\mathrm{OD}_{660}$ approximately equal to 0.4 . At this point, 1 $\mathrm{mM}$ isopropyl- $\beta$-D-thiogalactopyranoside (IPTG) was added to the culture for an additional 2-h incubation. Cells were harvested by centrifugation at $8,000 \mathrm{rpm}$ for $5 \mathrm{~min}$, washed, and resuspended in $50 \mathrm{ml}$ of buffer A (12 mM HEPES-NaOH pH 8.0, 4 mM Tris-HCl, pH 8.0, 1 mM EDTA-NaOH pH 8.0, 1 $\mathrm{mM}$ phenylmethylsulfonyl fluoride [PMSF], $1 \mathrm{mM}$ dithiothreitol [DTT], 10\% glycerol). Crude cell extracts were obtained by sonication of washed bacterial suspension five times ( $2 \mathrm{~min}$ each) in ice-cold conditions. The sonicated crude extract was then centrifuged at $11,000 \mathrm{rpm}$ for $30 \mathrm{~min}$. The supernatant was fractionated by ammonium sulfate precipitation. The fraction precipitated with 20 to $40 \%$ ammonium sulfate (KdgR), 40 to $60 \%$ CRP, 25 to $40 \%$ Pir, or 55 to $70 \%$ PecS was resuspended in $5 \mathrm{ml}$ of buffer A and dialyzed against three liters of the same buffer overnight. After removing insolubilized proteins of the dialysate by centrifugation at $11,000 \mathrm{rpm}$ for 10 min, the dialysate was degassed for $10 \mathrm{~min}$ and applied to a
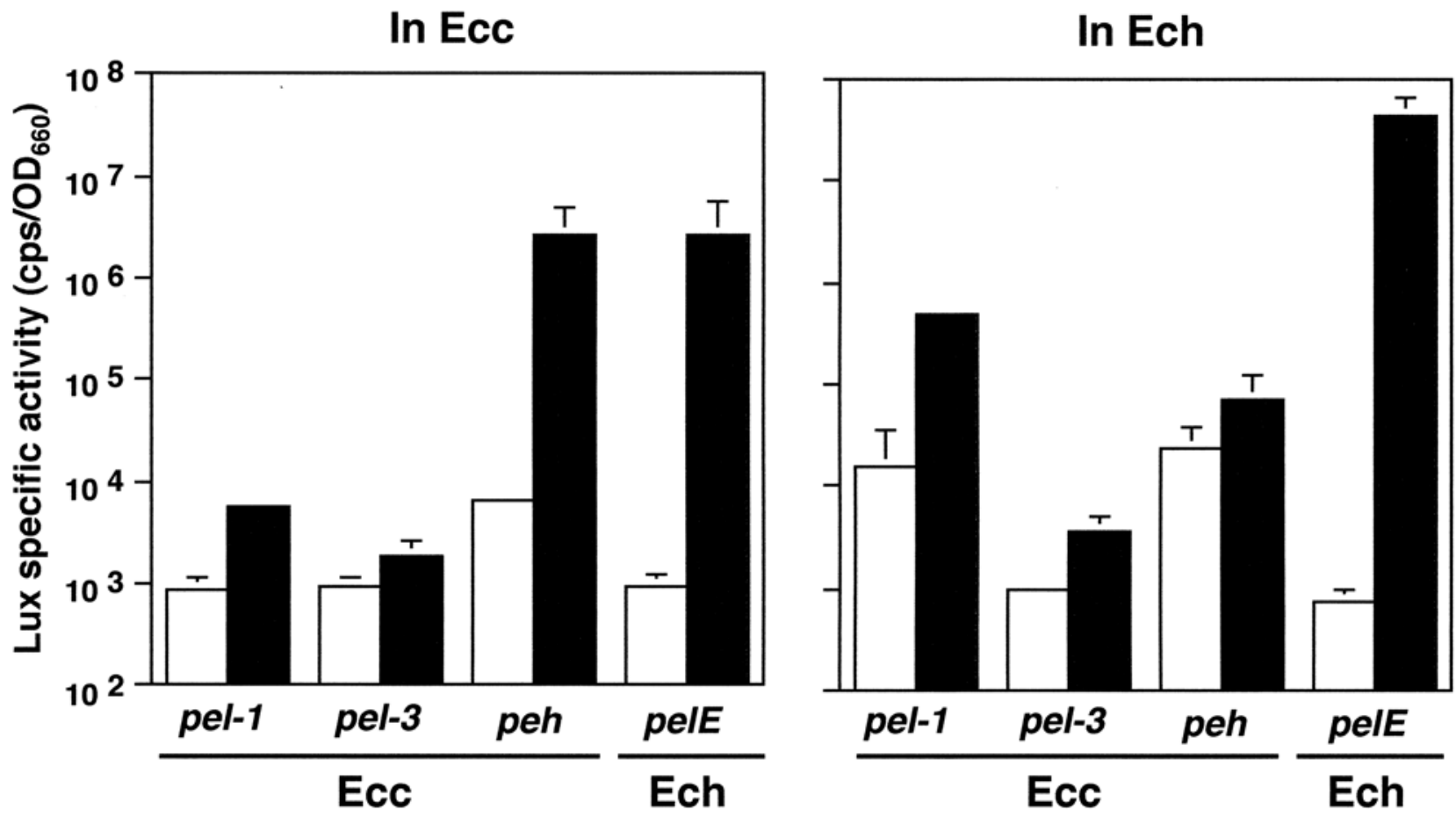

\section{In YP}

\section{In YP+PGA}

Fig. 6. Activity of Erwinia carotovora subsp. carotovora pel-1, pel-3, and peh and E. chrysanthemi pelE promoter-lux fusions in E. carotovora subsp. carotovora $\mathrm{EC} 1$ and in E. chrysanthemi EC16. One-tenth volume of overnight cultures in YP medium of E. carotovora subsp. carotovora EC1-N and E. chrysanthemi EC16 integrants was added to the same medium and was incubated at $27^{\circ} \mathrm{C}$ until mid-exponential growth phase $\left(\mathrm{OD}_{660}=\right.$ approximately 0.4). Following the preincubation, polygalacturonic acid (PGA) was added to final concentration of $0.2 \%$ for the induction. After $2 \mathrm{~h}$ incubation, photon production by the strains was measured every hour. The data was expressed as the mean of peak Lux-specific activities from at least three independent experiments. 
Heparin affinity column (POROS HE/P, $10 \mathrm{~mm} \times 100 \mathrm{~mm}$; Boehringer Mannheim, Mannheim, Germany). The column was washed with buffer A containing $0.1 \mathrm{M} \mathrm{KCl}$ and was eluted with a linear gradient of $\mathrm{KCl}$ from 0.1 to $1 \mathrm{M}$ at a flow rate of $5 \mathrm{ml} / \mathrm{min}$. Several fractions $(2 \mathrm{ml} /$ tube $)$ that formed a maximum peak in a UV curve were pooled and dialyzed against three liters of buffer A containing $50 \mathrm{mM} \mathrm{KCl}$. Proteins prepared by this two-step purification procedure were estimated to be single by staining with Coomassie Brilliant Blue R250 after SDS-PAGE (data not shown). Purified protein solutions were stored at $-20^{\circ} \mathrm{C}$ after adding $100 \%$ glycerol $(50 \%$, final). The protein concentration was determined using a BioRad Protein Assay (Bio-Rad, Hercules, CA, U.S.A.) solution with bovine serum albumin (BSA) as the standard.

\section{Gel-mobility shift assay.}

Standard procedures were performed as described by Ausubel and associates (1987) with minor modifications. Gelmobility shift assays were carried out in $10 \mu \mathrm{l}$ of reaction mixtures containing $12 \mathrm{mM}$ HEPES-NaOH, $\mathrm{pH}$ 8.0, $4 \mathrm{mM}$ Tris$\mathrm{HCl}, \mathrm{pH}$ 8.0, $0.1 \mathrm{mM}$ EDTA-NaOH, pH 8.0, $50 \mathrm{mM} \mathrm{KCl}, 10$ $\mathrm{mM} \mathrm{MgCl} 2,10 \mathrm{mM} \mathrm{CaCl}_{2}, 0.1 \mathrm{mM}$ PMSF, $1 \mathrm{mM}$ DTT, $10 \%$ glycerol, $1 \mu \mathrm{g}$ poly (dI-dC)-(dI-dC) (Amersham Pharmacia Biotech Inc., Piscataway, NJ, U.S.A.) as the bulk carrier DNA, 2 $\mu \mathrm{g}$ BSA, $10 \mathrm{fmol}$ of labeled DNA probe $\left(5 \times 10^{4} \mathrm{cpm}\right)$, and various amounts of purified protein. After incubation for 30 min at $27^{\circ} \mathrm{C}$, the reaction mixtures were loaded onto a $4 \%$ polyacrylamide gel $(15 \times 15 \mathrm{~cm})$ in low-ionic strength buffer (6.7 mM Tris- $\mathrm{HCl}, \mathrm{pH} 7.5,3.3 \mathrm{mM}$ sodium acetate, $\mathrm{pH} 6.0$, and $1 \mathrm{mM}$ EDTA-NaOH, $\mathrm{pH}$ 8.0) or in high-ionic strength buffer (50 mM Tris-HCl, pH 8.5, $380 \mathrm{mM}$ glycine, and $2 \mathrm{mM}$ EDTA-NaOH, pH 8.0) and electrophoresed in the same buffer

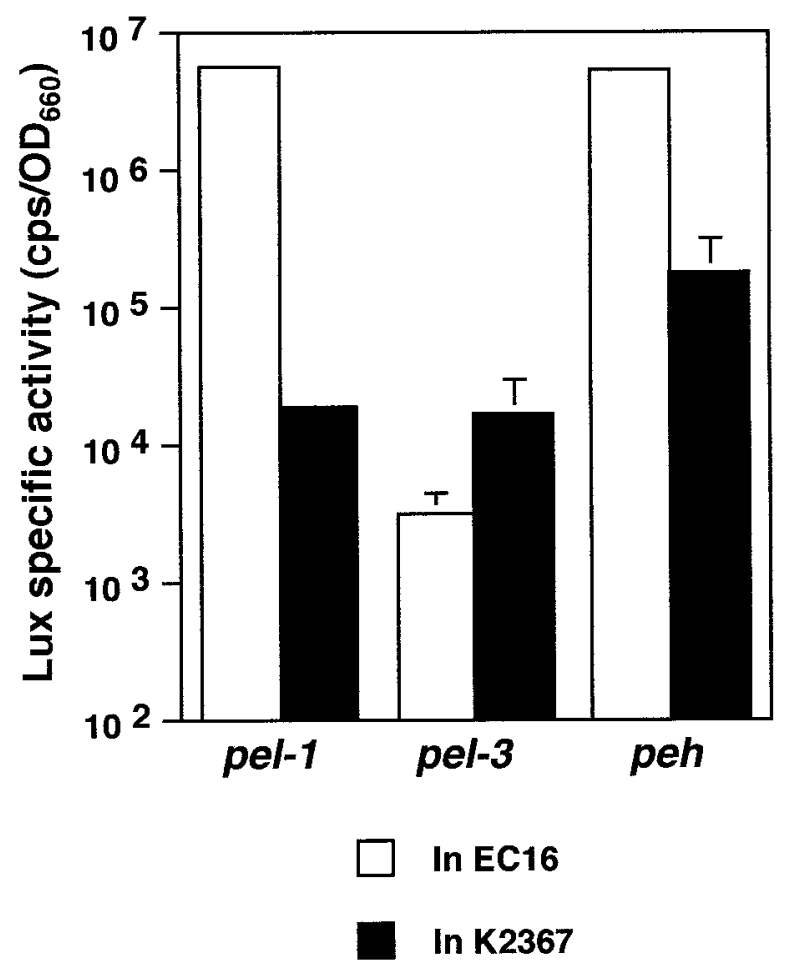

Fig. 7. Activity of Erwinia carotovora subsp. carotovora pel-1, pel-3, and peh promoter-lux fusions in pir-deficient mutant of E. chrysanthemi EC16 (K2367). Promoter-lux fusion integrants in E. chrysanthemi EC16 and in $\mathrm{K} 2367$ were grown at $27^{\circ} \mathrm{C}$ in M63-glycerol minimal medium containing $0.2 \%$ polygalacturonic acid and $1 \%$ potato extract. When cell density reached $\mathrm{OD}_{660}=$ approximately 1.0 , photon production by the strains was measured every hour. The data was expressed as the mean of peak Lux-specific activities from at least three independent experiments. at $20 \mathrm{~mA}$ for $2 \mathrm{~h}$. The gel was then vacuum-dried and exposed to Hyperfilm (Amersham Pharmacia Biotech). For CRP, reaction mixtures, gel, and electrophoresis buffer contained 100 $\mu \mathrm{M}$ cAMP.

\section{Insertion of promoter-lux fusions into $E$. carotovora subsp. carotovora and $E$. chrysanthemi chromosomes.}

To construct promoter-lux fusions, promoter regions of pel-1 from pPEL1-R, pel-3 from pPEL3-R, and peh from $\mathrm{pPEH}-\mathrm{RL}$ were cloned into the multicloning sites of pHSK728 (Shen et al. 1992), yielding pPEL1-LUX, pPEL3-LUX, and pPEHLUX, respectively (Table 2). For E. carotovora subsp. carotovora $\mathrm{EC} 1$, these constructs were electroporated into an Escherichia coli HB101 harboring a helper plasmid pRK2013 for conjugation and a helper plasmid pMON7184 (Barry 1988) for Tn7 transposition. Then, the transformants were conjugated with EC1-N, which is a spontaneous $\mathrm{Nal}^{\mathrm{r}}$ mutant of EC1. The $\mathrm{Nal}^{\mathrm{r}}, \mathrm{Sp}^{\mathrm{r}}$, and $\mathrm{Tet}^{\mathrm{r}}$ transconjugants were selected. They were subcultured at least five times in YP medium without antibiotics. Colonies resistant to $\mathrm{Nal}$ and $\mathrm{Sp}$ but sensitive to Tet were selected tentatively as candidates. Single insertion into the chromosome was confirmed by Southern blot analysis using Sp/Stm gene (3.8-kb PstI-EcoRV fragment of pHSK728) as the probe. For E. chrysanthemi EC16, constructs were directly introduced by electroporation $(9.4 \mathrm{kV} / \mathrm{cm}, 160 \mu \mathrm{F}$, and $4 \mathrm{ohms})$ into EC16 containing a helper plasmid pMON7181 for Tn7 transposition. Then, the transformants resistant to $\mathrm{Sp}$ and $\mathrm{Gm}$ were selected. The rest of the procedures were performed as for E. carotovora subsp. carotovora $\mathrm{EC} 1$.

\section{Bioluminescence assay.}

Photon production by the promoter-lux fusion integrants was measured 10 times for $1 \mathrm{~s}$ by a chemiluminescence detector (Hamamatsu Photonics, Hamamatsu, Japan) every hour. The mean of 10 readings (counts per s) in $1 \mathrm{ml}$ divided by $\mathrm{OD}_{660}$ was used as the Lux-specific activity $\left(\mathrm{cps} / \mathrm{OD}_{660}\right)$. Peak Luxspecific activity during the incubation of each experiment was recorded. Data were expressed as the mean of peak Lux-specific activities from at least three independent experiments.

\section{ACKNOWLEDGMENT}

We are very grateful to K. Sayama and H. Dora for technical assistance with preparation of monoclonal antibodies. We also thank A. K. Chatterjee, the late N. T. Keen, and W. Nasser for generously providing strains of Erwinia spp., pMON7184, and pTP1, respectively. Thanks are extended to B. E. Hazen for revising the manuscript. Supported in part by grant-inaid (no. 12052210) and by a grant from the Ministry of Education, Culture, Sports, Science, and Technology of Japan (no. 13073).

\section{LITERATURE CITED}

Andersson, R. A., Eriksson, A. R. B., Heikinheimo, R., Mae, A., Pirhonen, M., Koiv, V., Hyytiainen, H., Tuikkala, A., and Palva, E. T. 2000. Quorum sensing in the plant pathogen Erwinia carotovora subsp. carotovora: The role of $\exp R_{E c c}$. Mol. Plant-Microbe Interact. 13:384-393.

Andersson, R. A., Koiv, V., Norman-Setterblad, C., and Pirhonen, M. 1999a. Role of RpoS in virulence and stress tolerance of the plant pathogen Erwinia carotovora subsp. carotovora. Microbiology 145:3547-3556.

Andersson, R. A., Palva, E. T., and Pirhonen, M. 1999b. The response regulator ExpM is essential for the virulence of Erwinia carotovora subsp. carotovora and acts negatively on the sigma factor $\operatorname{RpoS}\left(\sigma^{\mathrm{s}}\right)$. Mol. Plant-Microbe Interact. 12:575-584.

Ausubel, F. M., Brent, R., Kingston, R. E., Moore, D. D., Seidman, J. G., Smith, J. A., and Struhl, K. 1987. Current Protocols in Molecular Biology. John Wiley and Sons, New York.

Barras, F., van Gijsegem, F., and Chatterjee, A. K. 1994. Extracellular enzymes and pathogenesis of soft-rot Erwinia. Annu. Rev. Phytopathol. 32:201-234.

Barry, G. F. 1988. A broad-host-range shuttle system for gene insertion 
into the chromosomes of gram-negative bacteria. Gene 71:75-84.

Bourson, C., Favey, S., Reverchon, S., and Robert-Baudouy, J. 1993. Regulation of the expression of a pelA::uidA fusion in Erwinia chrysanthemi and demonstration of the synergistic action of plant extract with polygalacturonate on pectate lyase synthesis. J. Gen. Microbiol. 139:1-9.

Castillo, A., and Reverchon, S. 1997. Characterization of the pecT control region from Erwinia chrysanthemi 3937. J. Bacteriol. 179:4909-4918.

Collmer, A., and Keen, N. T. 1986. The role of pectic enzymes in plant pathogenesis. Annu. Rev. Phytopathol. 24:383-409.

Cui, Y., Chatterjee, A., Liu, Y., Dumenyo, C. K., and Chatterjee, A. K. 1995. Identification of a global repressor gene, rsmA, of Erwinia carotovora subsp. carotovora that controls extracellular enzymes, $\mathrm{N}-(3-$ oxohexanoyl)-L-homoserine lactone, and pathogenicity in soft-rotting Erwinia spp. J. Bacteriol. 177:5108-5115.

Cui, Y., Mukherjee, A., Dumenyo, C. K., Liu, Y., and Chatterjee, A. K. 1999. rsmC of the soft-rotting bacterium Erwinia carotovora subsp. carotovora negatively controls extracellular enzyme and harpin $\mathrm{Ecc}_{\mathrm{c}}$ production and virulence by modulating levels of regulatory RNA ( $r s m B$ ) and RNA-binding protein (RsmA). J. Bacteriol. 181:6042-6052.

Cui, Y., Chatterjee, A., and Chatterjee, A. K. 2001. Effects of the twocomponent system comprising GacA and GacS of Erwinia carotovora subsp. carotovora on the production of global regulatory $r \operatorname{smB}$ RNA,

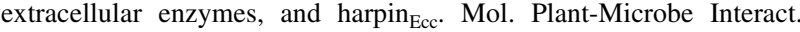
14:516-526.

Eriksson, A. R. B., Andersson, R. A., Pirhonen, M., and Palva, E. T. 1998. Two-component regulators involved in the global control of virulence in Erwinia carotovora subsp. carotovora. Mol. Plant-Microbe Interact. 11:743-752.

Figurski, D. H., and Helinski, D. R. 1979. Replication of an origin-containing derivative of plasmid RK2 dependent on a plasmid function provided in trans. Proc. Natl. Acad. Sci. U.S.A. 76:1648-1652.

Flego, D., Marits, R., Eriksson, A. R. B., Koiv, V., Karlsson, M.-B., Heikinheimo, R., and Palva, E. T. 2000. A two-component regulatory system, pehR-pehS, controls endopolygalacturonase production and virulence in the plant pathogen Erwinia carotovora subsp. carotovora. Mol. Plant-Microbe Interact. 13:447-455.

Franza, T., Sauvage, C., and Expert, D. 1999. Iron regulation and pathogenicity in Erwinia chrysanthemi 3937: Role of the Fur repressor protein. Mol. Plant-Microbe Interact. 12:119-128.

Harris, S. J., Shih, Y.-L., Bentley, S. D., and Salmond, G. P. C. 1998. The hexA gene of Erwinia carotovora encodes a LysR homologue and regulates motility and the expression of multiple virulence determinants. Mol. Microbiol. 28:705-717.

Hugouvieux-Cotte-Pattat, N., Dominguez, H., and Robert-Baudouy, J. 1992. Environmental conditions affect the transcription of the pectinase genes of Erwinia chrysanthemi 3937. J. Bacteriol. 174:78077818.

Hugouvieux-Cotte-Pattat, N., Condemine, G., Nasser, W., and Reverchon, S. 1996. Regulation of pectinolysis in Erwinia chrysanthemi. Annu. Rev. Microbiol. 50:213-257.

Hyytiainen, H., Montesano, M., and Palva, E. T. 2001. Global regulators ExpA (GacA) and $\mathrm{KdgR}$ modulate extracellular enzyme gene expression through the RsmA-rsmB system in Erwinia carotovora subsp. carotovora. Mol. Plant-Microbe Interact. 14:931-938.

Kolb, A., Busby, S., Buc, H., Garges, S., and Adhya, S. 1993. Transcriptional regulation by cAMP and its receptor protein. Annu. Rev. Biochem. 62:749-795.

Kotoujansky, A. 1987. Molecular genetics of pathogenesis by soft-rot Erwinias. Annu. Rev. Phytopathol. 25:405-430.

Kotoujansky, A., Lemattre, M., and Boistard, P. 1982. Utilization of a thermosensitive episome bearing transposon $\mathrm{Tn} 10$ to isolate $\mathrm{Hfr}$ donor strains of Erwinia carotovora subsp. chrysanthemi. J. Bacteriol. 150:122-131.

Liu, Y., Murata, H., Chatterjee, A., and Chatterjee, A. K. 1993. Characterization of a novel regulatory gene aepA that controls extracellular enzyme production in the phytopathogenic bacterium Erwinia carotovora subsp. carotovora. Mol. Plant-Microbe Interact. 6:299-308.

Liu, Y., Jiang, G., Cui, Y., Mukherjee, A., Ma, W.-L., and Chatterjee, A. K. 1999. $k d g R_{E c c}$ negatively regulates genes for pectinases, cellulase, protease, Harpin ${ }_{\mathrm{Ecc}}$, and a global RNA regulator in Erwinia carotovora subsp. carotovora. J. Bacteriol. 181:2411-2422.

Ma, W.-L., Cui, Y., Liu, Y., Dumenyo, C. K., Chatterjee, A., and Chatterjee, A. K. 2001. Molecular characterization of global regulatory RNA species that control pathogenicity factors in Erwinia amylovora and Erwinia herbicola pv. gypsophilae. J. Bacteriol. 183:1870-1880.

Miller, J. H. 1972. Experiments in molecular genetics. Cold Spring Harbor Laboratory Press, Cold Spring Harbor, N.Y.

Mukherjee, A., Cui, Y., Ma, W.-L., Liu, Y., Ishihama, A., Eisenstark, A. and Chatterjee, A. K. 1998. RpoS (sigma-S) controls expression of
rsmA, a global regulator of secondary metabolites, harpin, and extracellular proteins in Erwinia carotovora. J. Bacteriol. 180:3629-3634.

Mukherjee, A., Cui, Y., Ma, W.-L., Liu, Y., and Chatterjee, A. K. 2000. hexA of Erwinia carotovora ssp. carotovora strain Ecc71 negatively regulates production of RpoS and $r \sin B$ RNA, a global regulator of extracellular proteins, plant virulence and the quorum-sensing signal, $N$ (3-oxohexanoyl)-L-homoserine lactone. Environ. Microbiol. 2:203215.

Murata, H., McEvoy, J. L., Chatterjee, A., Collmer, A., and Chatterjee, A K. 1991. Molecular cloning of an aepA gene that activates production of extracellular pectolytic, cellulolytic, and proteolytic enzymes in $\mathrm{Er}$ winia carotovora subsp. carotovora. Mol. Plant-Microbe Interact. 4:239-246.

Murata, H., Chatterjee, A., Liu, Y., and Chatterjee, A. K. 1994. Regulation of the production of extracellular pectinase, cellulase, and protease in the soft rot bacterium Erwinia carotovora subsp. carotovora: Evidence that aepH of E. carotovora subsp. carotovora 71 activates gene expression in $E$ carotovora subsp. carotovora, E. carotovora subsp. atroseptica, and Escherichia coli. Appl. Environ. Microbiol. 60:3150-3159

Nasser, W., Condemine, G., Plantier, R., Anker, D., and Robert-Baudouy, J. 1991. Inducing properties of analogs of 2-keto-3-deoxygluconate on the expression of pectinase genes of Erwinia chrysanthemi. FEMS (Fed. Eur. Microbiol. Soc.) Lett. 81:73-78.

Nasser, W., Reverchon, S., Condemine, G., and Robert-Baudouy, J. 1994 Specific interactions of Erwinia chrysanthemi $\mathrm{KdgR}$ repressor with different operators of genes involved in pectinolysis. J. Mol. Biol. 236:427-440

Nasser, W., Robert-Baudouy, J., and Reverchon, S. 1997. Antagonistic effect of CRP and KdgR in the transcription control of the Erwinia chrysanthemi pectinolysis genes. Mol. Microbiol. 26:1071-1082.

Nasser, W., Bouillant, M. L., Salmond, G. P. C., and Reverchon, S. 1998. Characterization of the Erwinia chrysanthemi expI-expR locus directing the synthesis of two $\mathrm{N}$-acyl-homoserine lactone signal molecules. Mol. Microbiol. 29:1391-1405.

Nasser, W., Shevchik, V. E., and Hugouvieux-Cotte-Pattat, N. 1999. Analysis of three clustered polygalacturonase genes in Erwinia chrysanthemi 3937 revealed an anti-repressor function for the PecS regulator. Mol. Microbiol. 34:641-650.

Nasser, W., Faelen, M., Hugouvieux-Cotte-Pattat, N., and Reverchon, S. 2001. Role of the nucleoid-associated protein H-NS in the synthesis of virulence factors in the phytopathogenic bacterium Erwinia chrysanthemi. Mol. Plant-Microbe Interact. 14:10-20.

Nomura, K., Nasser, W., Kawagishi, H., and Tsuyumu, S. 1998. The pir gene of Erwinia chrysanthemi EC16 regulates hyperinduction of pectate lyase virulence genes in response to plant signals. Proc. Natl. Acad. Sci. U.S.A. 95:14034-14039.

Nomura, K., Nasser, W., and Tsuyumu, S. 1999. Self-regulation of Pir, a regulatory protein responsible for hyperinduction of pectate lyase in Erwinia chrysanthemi. Mol. Plant-Microbe Interact. 12:385-390.

Perombelon, M. C. M., and Kelman, A. 1980. Ecology of the soft rot Erwinias. Annu. Rev. Phytopathol. 18:361-387.

Pirhonen, M., Flego, D., Heikinheimo, R., and Palva, E. T. 1993. A small diffusible signal molecule is responsible for the global control of virulence and exoenzyme production in the plant pathogen Erwinia carotovora. EMBO (Eur. Mol. Biol. Organ.) J. 12:2467-2476.

Praillet, T., Nasser, W., Robert-Baudouy, J., and Reverchon, S. 1996. Purification and functional characterization of $\mathrm{PecS}$, a regulator of virulence-factor synthesis in Erwinia chrysanthemi. Mol. Microbiol. 20:391-402.

Reverchon, S., Nasser, W., and Robert-Baudouy, J. 1991. Characterization of $k d g R$, a gene of Erwinia chrysanthemi that regulates pectin degradation. Mol. Microbiol. 5:2203-2216.

Reverchon, S., Nasser, W., and Robert-Baudouy, J. 1994. pecS: A locus controlling pectinase, cellulase and blue pigment production in Erwinia chrysanthemi. Mol. Microbiol. 11:1127-1139.

Reverchon, S., Expert, D., Robert-Baudouy, J., and Nasser, W. 1997. The cyclic AMP receptor protein is the main activator of pectinolysis genes in Erwinia chrysanthemi. J. Bacteriol. 179:3500-3508.

Reverchon, S., Bouillant, M. L., Salmond, G. P. C., and Nasser, W. 1998. Integration of the quorum-sensing system in the regulatory networks controlling virulence factor synthesis in Erwinia chrysanthemi. Mol. Microbiol. 29:1407-1418.

Robert-Baudouy, J., Nasser, W., Condemine, G., Reverchon, S., Shevchik, V. E., and Hugouvieux-Cotte-Pattat, N. 2001. Pectic enzymes of Erwinia chrysanthemi, regulation and role in pathogenesis: Pages 221-268 in: Advances in Molecular Genetics of PlantMicrobe Interactions. Vol. 5. G. Stacey, and N. T. Keen, eds. American Phytopathological Society Press, St. Paul, MN, U.S.A.

Rouanet, C., Nomura, K., Tsuyumu, S., and Nasser, W. 1999. Regulation 
of pelD and pelE, encoding major alkaline pectate lyases in Erwinia chrysanthemi: Involvement of the main transcriptional factors. J. Bacteriol. 181:5948-5957.

Sambrook, J., Fritsch, E. F., and Maniatis, T. 1989. Molecular Cloning: A Laboratory Manual, 2nd ed. Cold Spring Harbor Laboratory Press, Cold Spring Harbor, NY, U.S.A.

Shen, H., Gold, S. E., Tamaki, S. J., and Keen, N. T. 1992. Construction of a Tn7-lux system for gene expression studies in gram-negative bacteria. Gene 122:27-34.

Staskawicz, B. J., Dahlbeck, D., Keen, N. T., and Napoli, C. 1987. Molecular characterization of cloned avirulence genes from race 0 and race 1 of Pseudomonas syringae pv. glycinea. J. Bacteriol. 169:5789-5794.

Surgey, N., Robert-Baudouy, J., and Condemine, G. 1996. The Erwinia chrysanthemi pecT gene regulates pectinase gene expression. J. Bacteriol.
178:1593-1599.

Thomson, N. R., Cox, A., Bycroft, B. W., Stewart, G. S. A. B., Williams, P., and Salmond, G. P. C. 1997. The Rap and Hor proteins of Erwinia, Serratia and Yersinia: A novel subgroup in a growing superfamily of proteins regulating diverse physiological processes in bacterial pathogens. Mol. Microbiol. 26:531-544.

Thomson, N. R., Nasser, W., McGowan, S., Sebaihia, M., and Salmond, G. P. C. 1999. Erwinia carotovora has two KdgR-like proteins belonging to the IclR family of transcriptional regulators: Identification and characterization of the RexZ activator and the KdgR repressor of pathogenesis. Microbiology 145:1531-1545.

Zink, R. T., Engwall, J. K., McEvoy, J. L., and Chatterjee, A. K. 1985. recA is required in the induction of pectin lyase and carotovoricin in Erwinia carotovora subsp. carotovora. J. Bacteriol. 164:390-396. 